NBER WORKING PAPERS SERIES

PRODUCTIVITY AND MACHINERY INVESTMENT:

A LONG RUN LOOK 1870-1980

J. Bradford De Long

Working Paper No. 3903

NATIONAL BUREAU OF ECONOMIC RESEARCH

1050 Massachusetts Avenue

Cambridge, MA 02138

November 1991

This paper is part of NBER's research program in Growth. Any opinions expressed are those of the author and not those of the National Bureau of Economic Research. 
NBER Working Paper \#3903

November 1991

PRODUCTIVITY AND MACHINERY INVESTMENT:

A LONG RUN LOOK 1870-1980

\begin{abstract}
Over the past century the long-run growth of six economies shows a strong association between investment in machinery and economic growth that holds both within and across nations and periods. A similar strong association holds for the post-world War II period for a broader cross section of nations. A number of considerations suggest that this association is causal, and that a high rate of machinery investment is a necessary prerequisite for rapid long-run productivity growth - a hypothesis also supported by narratives from the history of technology.
\end{abstract}

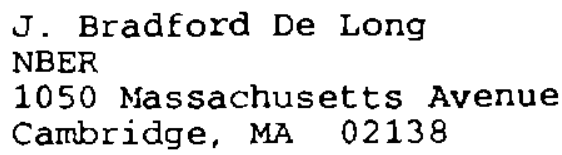




\title{
Productivity and Machinery Investment: A Long Run Look 1870-1980
}

\author{
J. BRADFORD DE LONG
}

\section{Introduction}

Machinery investment and productivity growth are strongly associated over the past century in a sample of six currenlly-industrialized nations - Canada, Germany, Italy, Japan, the United Kingdom, and the United States. A similar association holds since World War II for a broad cross-section of nations. ${ }^{1}$ Many have noted such an association in individual cases and for shorter periods. ${ }^{2}$ Moreover, there are signs that a

J. Bradford De Long is Frederick S. Danziger Associate Professor of Economics at Harvard University, and John M. Olin Fellow at the National Bureau of Economic Research, Cambridge, MA 02138. He would like to thank Timothy Hatton, Knick Harley, Chad Jones, Ian McLean, Andrei Shleifer, Lany Summers, Alan Taylor, Robert Waldmann, and Jeffrey Williamson for helpful discussions and comments; Hoing Quan Vu and Marco Becht for excellent research assistance, and the National Science, Sloan, Olin, and Paskus Foundations. as well as the NBER, for financial support.

${ }^{1}$ See Bradford De Long and Lawrence Summers, "Equipment luvestment and Economic Growth," Quarterty Journat of Economics 106 (Maly 1991), pp. 445-502.

2For example, Rolf Hayn, "Capital Formation and Argentina's Price Cost Structure," Review' of" Economics and Statistics 44 (1962) pp. 340-3, and Carlos Dilaz-Alejiundro, Essays on the Economic History of the Argentine Republic (New Haven, CN: Yale University Press, 1970), argued that Argentina's extratordinarily poor performance since World War II was due to al low 
large part of this association is causal in that high machinery investment generates rapid growth. The strong association between machinery investment and productivity growth suggests a fundamental link of growth with mechanization, with the acquisition of machinery that embodies the technologies of the Industrial Revolution.

This article begins by sketching some issues at stake in the debate over the role of machinery accumulation in growth. Section II turns to the reliability of the data. Section III documents the association of machinery investment and growth. Section IV discusses causality--does high machinery investment cause fast growth, or does fast growth lead to high machinery investment? And section $V$ tries to fit the macro patterns to the micro narratives of historians of technology.

Historians have long stressed the role of mechanization in the multiplication of productivity over the past two centuries. Industrial nations are more than eight times as wealthy as a century ago because they can and have poured resources into making the machines that embody the technologies of the Industrial Revolution. Factors supporting high machinery investment are given a prominent role in historians' narratives, and are in the forefront of the pictures drawn by Rostow and Gerschenkron, by Rosenberg, Landes, and Pollard, and by many, many

rate of machinery investment in machinery resulting fron counterproductive policies. T.P. HIill, "Growth and Investment According to Intemational Comparisons." Economic Journal (June 1964), pp. 287-304, found a strong bivariate association between nlachinery investment and growth over 1954-62 in OECD countries. De Long and Summers, "Equipment Investment and Economic Growth," found a strong association between machinery investment and growth over 1950-85 for a broad sample of nations, as did Charles Jones, "Economic Growth and Producer Durables Prices" (Cambridge, MA: M.I.T. xerox, 1990). 
others. ${ }^{3}$

Development and growth economisss have taken another direction. They concluded that accumulation had been overstressed, and other factors-like formal education, the exploitation of scale, appropriate terms of trade, and so on-were more central. ${ }^{4}$ Studies in the growth account ing tradition of Solow have been interpreted as revealing that capital deepening is responsible for only a small part of productivity growth.5 The general drift of this line is that rapid machinery accumulation is neither sufficient nor necessary for economic growth: formal education, the overcoming of bottlenecks, and the removal of inefficiencies in the use of resources are more strategic factors in long-run growth than the accumulation of machinery.

\footnotetext{
${ }^{3}$ See W.W. Rostow, Stages of Economic Grow'h (Cambridge: Cambridge University Press. 1960); Alexander Gerschenkron, Economic Backwardness in Historical Perspective (Cambridge, MA: Harvard University Press, 1962); Nathan Rosenberg, "Capital Goods. Teclunology, and Economic Growth," Oxford Economic Papers 15 (1963), pp. 217-28; David Landes, The Unbound Prometheus (Cambridge: Cambridge University Press, 1969); Sidney Pollard, Peacefinl Conquest (Oxford: Oxford Univesrity Press, 1981); and Jérôme-Adolphe Blanqui, Histoire de l'Economie Politique in Europe (1837; English trans. Emily Leonard from the fourth French ed.; New York: G.P. Putnam's Sons, 1880).

${ }^{4}$ W.W. Rostow, Theorists of Economic Growth (New York: Oxford University Press, 1990), surveys the development of theories of economic growth. Colin Clark, Conditions of Economic Progress (London: Macmillan, 3d ed. 1957), was among the first to argue that capital deepening was $n o t$ responsible for the bulk of growth.

5 For example, Mrinal Datta-Chadhuri's claim in "Market Failure and Govenment Failure," Journal of Economic Perspectives 4:3 (Summer 1990), pp. 25-40, that "Solow ... demonstrated that only a small part of...growlh...can be explained by...physical capital." Robert Solow's "Technical Change and the Aggregate Production Function," Revie'n' of Economics and Statistics 39 (August 1957), pp. 312-20 is more restrained. See also Edward Denison, Why Growth Rates Differ (Washington, DC: Brookings Institution, 1967).
} 
This paper reaffirms the Gersclienkronian view. The macro patterns it finds suggest that machinery investment is in a sense the strategic factor in economic growtl. Moreover, the macro pattern fits well with the micro narratives of technological historians. Rosenberg is only one of many that argue on the basis of micro studies of innovation that the construction, acquisition, and installation of machines is a key link in the process of economic development. ${ }^{6}$ This paper suggests that the trees sketched by technological historians give a good idea of the forest as well.

\section{Dała}

This study covers six nations-Canada, ${ }^{7}$ Germany, ${ }^{8}$ Italy, Japan, the United Kingdom, and the United States-over eight periods-1870 to 1885,1885 to 1900,1900 to 1913,1913 to 1929,1929 to 1938,1938 to 1950 , and 1950 to 1965 , and 1965 to 1980 . The fifteen-year frequency of observation, with some dates offset to better match the cycle and the eras of war and peace, ${ }^{9}$ was chosen to focus on longer-run shifts in growth rates instead of shorter-run cyclical fluctuations.

\footnotetext{
${ }^{6}$ See Rosenberg, "Technological Change in the Machine Tool Industry," Journal of Economic' History 23 (December 1963), pp. 414-43.

${ }^{7}$ Data for Canada is relatively poor before 1929 , and is not used.

8 West Germany after World War Il.

${ }^{9}$ The 1913-1929 period ends on the eve of the Great Depression, thus containing all of World War I and subsequent business cycles leading up to the end of the 1920's boom. And the 1938 50 period ends when post-World War Il reconstruction had been substantially completed.
} 
The nations were chosen on the basis of data availability. Long-run national product estimates of the quality necessary are rare. These six countries are those with the best data. They make up a substantial part of the industrial world, accounting for roughly sixty percent of total world economic product today and for perhaps forty percent in 1870.10

In choosing among different estimates of growth rates and investment shares, this paper stays as close as possible to the numbers compiled by Maddison, whose database has had a substantial influence on conceptions of long-run growth in comparative perspective. ${ }^{11}$ The esti-

$10 \mathrm{~A}$ seventh once-rich nation, Argentina, is of extraordinary interest: its post-World War II relative economic collapse has carried it from the First to the Third World. Inclusion of Argentina would help to control for a potential sample selection problen-since all of the nations in the sample have done well, perhaps they are unrepresentative-but it cannot be reliably included in the statistical analysis. If Argentinian data is included, the coefficients estimated for the regressions are very similar, but the standard errors of the coefficients are much smaller.

11 Out of those cross-country estimates available, Maddison's database one of the most comprehensive and certainly the best documented. See Angus Maddison, Phases of Capitalist Devetopment (New York: Oxford University Press, 1982), and Economic Growth in the Twenticth Century (Paris: OECD, 1989). However, Maddison's estimates are not immune from challenge. See Jan de Vries, "The Decline and Rise of the Dutch Economy," in G. Saxonhouse and G. Wright. eds., Technique, Spirit, and Form in the Making of the Modern Economies: Essays in Honor of William H. Parker (Supplement 3, in 1984, to Research in Economic History), for a convincing argument that Maddison's estimates of Dutch nineteenth century growth are substantially awry. J. Bradford De Long, "Productivity Growth, Convergence, and Welfare: Comment," American Economic Review' 78 (December 1988), pp. 1138-1154, makes some skeptical observations on some of the estimates in Phases of Capitalist Developmen., particularly for Japan and Scandinavia.

Nevertheless, future clallengers and revisors of Maddison must begin where his work leaves off-and his work has made that of potential revisionists mucin easier. For estimates of comparitive living standards made via wage levels compared using contemporary purchasing power parity bencimarks, see Jeffrey Williamson. "Tlie Evolution of Global Labor Markets" (Cambridge. MA: Harvard University xerox, 1991). Williamson's estimates find sufficiently large discrepancies to be worrisome, but not large enough to fully invalidate Maddison's database. On the other 
mates of output per capita used have been drawn from his Phases of Capitalist Development. These estimates of relative past output levels are derived by extrapoliting growlh rates as given by nation-specific studies backward from a current benchmark. Growth is measured using different price vectors: the prices in which Japanese growth from 196579 is calculated are not the relative prices in which German growth from 1900-13 is calculated. There is thus no good reason to believe that the different output growth rates reported by Maddison are consistent.

The estimates of machinery investment are compiled from individual national sources. 12 The same potential inconsistencies are thus present in

hand, Michael Mulhall's Industries and Wealth of Nations (London: Longmans, Greene, and Co., 1896) contains contemporary estimates of the industries and wealth of nations that have a correlation for the sample used here (excluding Japan) of 0.98 with Maddison's estimates.

12 Sources of pre-World War II datil on capital stock estimates and investment shares are as follows. For Canada, only official post-1929 data are available. A more detailed picture of earlier growth could be constructed by extrapolating from the individual years covered by O.J.

Firestone, Canada's Economic Development (Ottawa: Department of Trade and Commerce, 1953), but the data will not bear the weight of such extrapolation. For Germany, the estimates used are Maddison's revisions in Phases of Capitalist Developmem of W.G. Hoffman et wl.'s estimates in Das Wachstum der deutschen Wirtschaft (Berlin: Springer, 1965). Before 1929, the underlying estimates of the German capital stock are "net concept" estimates. All other estimates used are "gross concept" estimates. Italian machinery and equipment data are derived from Giorgio Fua, ed., Lo Sviluppo Economico in Iralia (Mllano: Angeli, 1969), for the pre-World War II period, and from Robert Summers and Alan Heston, "The Penn World Table, Version V." Quatrerly Journal of Economics 106 (May 1991), pp. 327-68. thereafter. Japanese data are derived from Kazushi Ohkawa, Estimates of Long-Tetm Economic Statistics of Japan since 1868 (Tokyo: Toyo Keizai Shimpo Sha, 1966), for the pre-World War Il period, and from "Penn World Table V" for the post-World War Il period. United Kingdom data are taken from C.H. Feinstein, National Income, Expenditure, and Output in the United Kingtom (Cambridge: Cambridge University Press, 1972). For the United States, the estimates for the post-1929 period are the official Department of Commerce estimates; the estimates for the pre-1929 period are derived from Simon Kuznets, Capital in the American Economy (Princeton, NJ: Princeton 
the investment estimates as well. Prices used differ across countries and in some cases across periods. This paper bets that such inconsistencies do not corrupt the conclusions, but it cannot be used to draw strong lessons about characteristics and patterns of growth in any one country relative to others in the sample. Statements about the deviations of national patterns from the average pattern found in the sample derived from the data used in this paper may well be misleading. But conclusions about long-run growth in the "typical" industrialized nation are more secure, for errors made in describing the quantitative shape of growth in of individual nations cancel to some degree when averages are considered.

The investment estimates used in this paper are typically equal to gross investment less retirements. It is larger than "net investment," which subtracts depreciation on existing capital. It is smaller than "gross investment." The concept used here is the concept appropriate for aggregate production functions: it measures the change in physical capital for use in production.

\section{Machinery Accumulation and Productivity}

Figure I plots machinery investment shares and output per capita growth. The association is strong, capturing more than half of the variance of output per capita growth. The machinery coefficient is large: 
each one percentage point rise in machinery investment as a share of output is associated with an increase of more than one-half a percent per year in output per capita growth.

Figure I: Machinery Investment and Output per Capita Growth

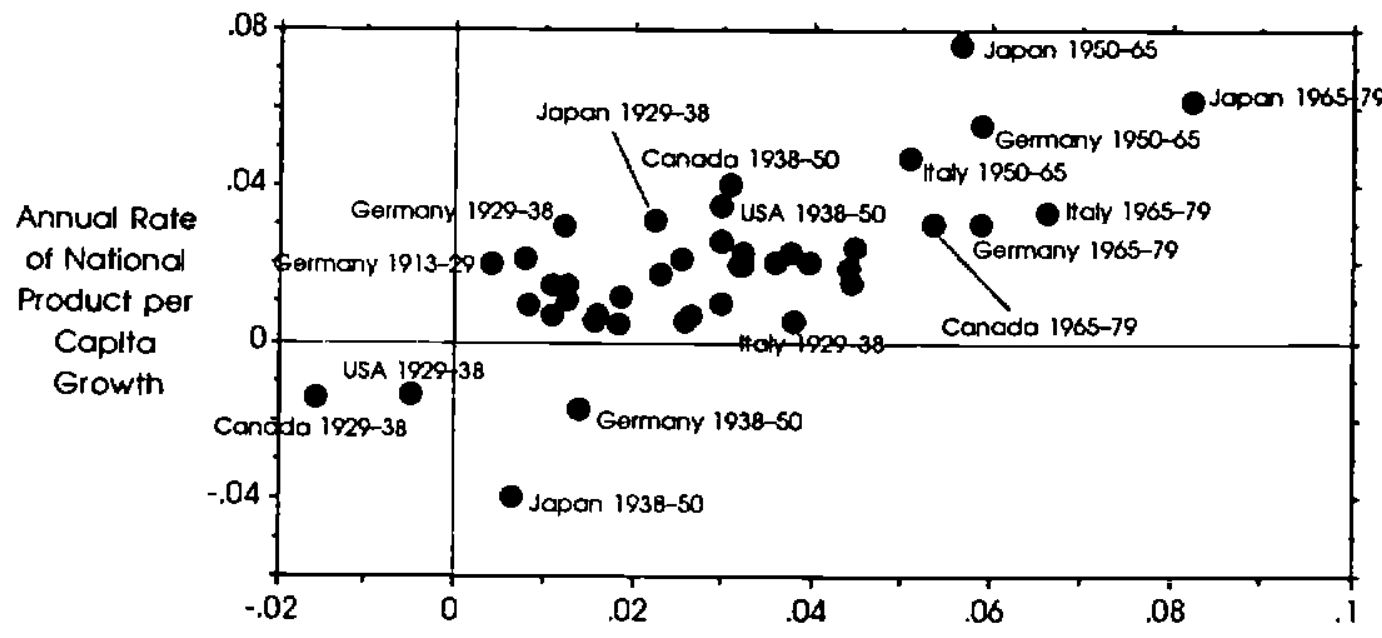

Annual Rate of Change of Gross Machinery and Equipment Capital Stock, as a Proportion of National Product

Source: Author's calculations as described in the text.

The highest-growth highest-investment points come after World War II. This "Great Keynesian Boom" saw growth more rapid than any previous era. Perhaps it is a structural break, and the association of machinery and growth is a reflection of this break. This is not the case. Post1950 growth has been no more rapid on average than predicted from 
pre-1950 relations. 13

\begin{tabular}{|c|c|c|c|c|c|c|c|}
\hline \multirow[t]{4}{*}{ Spocification } & $\begin{array}{l}\text { Machinery } \\
\text { Investment }\end{array}$ & $\begin{array}{c}\text { Non- } \\
\text { Residenlial } \\
\text { Construction } \\
\text { Invesiment. }\end{array}$ & $\begin{array}{l}\text { Extra Elfecl of } \\
\text { Machinery: } \\
\text { T-Statistic }\end{array}$ & $\begin{array}{l}\text { Population } \\
\text { Growth Rate }\end{array}$ & $\begin{array}{l}\text { Output/Capita } \\
\text { Level Relative } \\
\text { to U.S. }\end{array}$ & $\mathrm{A}^{2}$ & SEE \\
\hline & $\begin{array}{l}0.561 \\
(0.157)\end{array}$ & $\begin{array}{l}0.192 \\
(0.117)\end{array}$ & 1.47 & $\begin{array}{l}-0.481 \\
(0.504)\end{array}$ & $\begin{array}{l}-0.011 \\
(0.009)\end{array}$ & 0.587 & 0.0139 \\
\hline & $\begin{array}{l}0.624 \\
(0.147)\end{array}$ & $\begin{array}{c}0.167 \\
(0.115)\end{array}$ & 1.91 & $\begin{array}{l}-0.543 \\
(0.504)\end{array}$ & & 0.572 & 0.0140 \\
\hline & $\begin{array}{r}0.599 \\
(0.151)\end{array}$ & $\begin{array}{c}0.127 \\
(0.094)\end{array}$ & 2.10 & & $\begin{array}{l}\cdot 0.011 \\
(0.009)\end{array}$ & 0.577 & 0.0139 \\
\hline Nation Dummies" & $\begin{array}{l}0.675 \\
(0.169)\end{array}$ & $\begin{array}{l}0.101 \\
(0.129)\end{array}$ & 2.07 & $\begin{array}{l}-0.373 \\
(0.609)\end{array}$ & $\begin{array}{l}-0.049 \\
(0.021)\end{array}$ & 0.665 & 0.0135 \\
\hline Era Dummies" & $\begin{array}{l}0.736 \\
(0.225)\end{array}$ & $\begin{array}{l}0.175 \\
(0.138)\end{array}$ & 1.80 & $\begin{array}{l}-0.741 \\
(0.644)\end{array}$ & $\begin{array}{l}-0.003 \\
(0.011)\end{array}$ & 0.640 & 0.0144 \\
\hline $\begin{array}{l}\text { Nation \& Era".* } \\
\text { Dummies }\end{array}$ & $\begin{array}{l}1.227 \\
(0.266)\end{array}$ & $\begin{array}{l}0.046 \\
(0.140)\end{array}$ & 3.35 & $\begin{array}{l}-2.212 \\
(0.907)\end{array}$ & $\begin{array}{l}0.031 \\
(0.026)\end{array}$ & 0.758 & 0.0130 \\
\hline
\end{tabular}

The U.S. adone has a significant nation dummy: +0.0208.

"None of the era dummies are significant.

"."The 1965-79 era coelficient has a signilicant negative coefficient, the Canada and the U.S.A. nation coefficients are significant and positive.

Source: As described in the text.

13 Little of rapid post-1950 growth in output or investment in machinery can be attributed to replacement of wartime losses. Only Japan and Germany were below their pre-World War II growth paths by 1950 , and they were not far below. By 1965, all six of the countries were above not only their pre-World War II but also their pre-Great Depression growth paths. See Alan Milward, The Reconstruction of Western Europe (Berkeley, CA: University of Califomia Press). 
Table I reports regressions of output per capita growth on investment in machinery and on additional variables: the level of output per capita relative to America (to take account of possible "convergence" as follower countries more quickly retrace the steps of leaders), the rate of population growth (to take account of the burdens of capital widening), the share of non-residential construction investment in national product (to control for the increase in productivity produced by other forms of investment besides equipment), and separate indicator variables for each nation and era (to partially control for the host of additional influences, nation- and era-specific, on the rate of economic growth). ${ }^{14}$ Table $I$ also reports the t-statistic on the difference between the coefficient on investment in machinery and the coefficient on investment in general.

This reveals the significance of the additional correlation between growth and machinery above the correlation between growth and investment in general. Consider just the first regression, with the lowest such t-statistic: 1.47. An observer thinking the odds were 1-1 for machinery having a stronger association with growth than other, investment but having no view as to the magnitude of the differential would, if this regression came as new information, believe that the odds were 14-1 that machinery had the stronger association.

\footnotetext{
${ }^{14}$ Still other additional variables were also included in results not shown. Direct measures of education are noted below. "Defeat in war" indicator variables, and variables measuring the orientation of exports toward primary products or manufactures did not have a noticeable effect on the machinery investment coefficient.
} 
The nation and era indicators rarely achieve statistical significance. 15 It is interesting that there are not significant nation and era effects. Such would proxy for important variables-like rates of education, impacts of economic policies, or the functioning of the international regime-with differential effects across nations and eras. There are surely important determinants of growth other than population growth, machinery and other forms of investment, and "catch-up." But such determinants are neither persistent within any nation nor pervasive in any era. ${ }^{16}$

Regressions with both nation and era indicator variables included generate very large coefficients on the machinery investment variable and implausible estimates of the relationship between population and output per capita growth. Inclusion of both sets soaks up too much of identifying variance, producing coefficient estimates that are untrustwor-

15 Nation effects are measured relative to Germany. Era effects are neasured relative to the initial $1870-85$ period. The U.S. indicator is one of the few that is significant: the U.S. has grown over the past century about two percent per year faster than would be expected given its level of per capita national product relative to the other industrial nations and its rate of equipment investment. When the level of output per capita relative to the U.S. is dropped from the indepen dent variables, then the U.S. indicator variable loses its significance. The U.S. is an exception to the "convergence" toward average productivity levels for the set of industrial nations as a whole that is exhibited by other industrial economies. The U.S. has managed to maintain its productivity lead for an astonishingly long time. See Moses Abramovitz, "Catching Up, Forging Ahead, and Falling Behind," Journal of Economic History 46 (June 1986), pp. 385-406, and William Baumol, Sue Anne Beatty Blackman, and Edward Wolff, Productivity and American Leadership) (Cambridge, MA: M.I.T. Press, 1989). The positive U.S. indicator reveals not that the U.S. has grown faster than expected given its rate of machinery investment, but that it has grown faster than expected given its relative wealth.

${ }^{16}$ Adding direct measures of education, or of the change in education over a period, did not reduce the magnitude or significance of the coefficient on machinery. This may well have cone about only because official measurements are poor proxies for the actual stock of "human" or "organizational" capital that should enter a production function. 
thy. For this reason I place more reliance on the regressions without indicator variables, since their snall coefficients inmply that their omission cannot seriously bias the machinery coefficient estimate.

\section{Causality}

Few would argue that machinery investment is not to a degree dependent on output growth. Any influence generating faster growth will raise future profits. If firms anticipate such an increase they will invest in machinery to capture these future profits. The degree to which causation runs from investment to growth or from growth to investment is impossible to untangle with complete confidence. Nevertheless, three pieces of evidence suggest that a substantial share of causation runs from higher machinery investment to faster growth, not the reverse.

The first piece exploits the distinction between output growth and output per capita growth. If faster growth leads to higher investment because of the expectation of profits, investment might well respond equally to increases in output generated by productivity and increases generated by population. It should not matter much whether larger demand comes from having more consumers or richer consumers. ${ }^{17}$

\footnotetext{
${ }^{17}$ This insight is due to Barry Boswortl1, who suggested it to Lawrence Summers. De Long and Summers have used it to try to identify causality between machinery investment and growth in the post-World War II period.
} 


\section{Table II: Machinery Investment Regressed on Output per Capita and Population Growth}

\begin{tabular}{|c|c|c|c|c|c|}
\hline $\begin{array}{l}\text { Dependent } \\
\text { Variable }\end{array}$ & $\begin{array}{l}\text { Output } \\
\text { per Capita } \\
\text { Growth }\end{array}$ & $\begin{array}{l}\text { Population } \\
\text { Growth }\end{array}$ & $\begin{array}{l}\text { Non- } \\
\text { Residential } \\
\text { Construction } \\
\text { InvesIment }\end{array}$ & $\mathrm{A}^{2}$ & SEE \\
\hline Machinery Invesiment & $\begin{array}{c}0.710 \\
(0.104)\end{array}$ & $\begin{array}{c}0.319 \\
(0.383)\end{array}$ & & 0.556 & 0.0137 \\
\hline Mactinery Investment & $\begin{array}{c}0.513 \\
(0.121)\end{array}$ & $\begin{array}{l}-0.459 \\
(0.458)\end{array}$ & $\begin{array}{c}0.265 \\
(0.098)\end{array}$ & 0.627 & 0.0127 \\
\hline
\end{tabular}

Source: As descrlbed In the text.

Table II regresses machinery investment rates on output per capita and population growth rates, and shows a strong association between output per capita growth and machinery, and a weaker and imprecisely estimated association between population growth (holding output per capita constant) and machinery. Intensive growth that raises productivity and income levels is especially strongly associated with machinery investment.

A second piece of evidence is the recent, post-World War II experience as assessed by De Long and Summers, and by Jones. ${ }^{18}$ Today carries information about yesterday: the evidence of the present allows us

\footnotetext{
18"Equipment Investment and Economic Growth," and Jones, "Economic Growth and Producer Durables Prices." See also Steven Dowrick and Duc-Tho Nguyen, "OECD Comparative Catchup and Convergence," American Economic Review" 79 (December 1989), pp. 1010-30.
} 
different conclusions.

One obvious addition to the sample that would have led to different conclusions is the Soviet Union: since Stalin took absolute power at the end of the 1920's, the Soviet Union has invested extraordinarily heavily in machinery, and yet achieved productivity growth rates very poor by the standards of the industrial West. The inefficiency of the Soviet economy at translating inputs into outputs is one of the most fascinating and heartbreaking stories of the economic history of the twentieth century. Yet its experience serves as a warning to governments seeking to industrialize and accelerate growth: the type of machinery investment that leads to rapid growth appears to be the type generated by private firms and market allocation processes, not by central planners.

Nevertheless, the experience of the past century is that those countries that have grown most rapidly have been those that have invested very heavily in machinery. There is a strong case that their rapid growth is in large part due to this investment: it enabled their workers and firms to gain experience at using and thus master the technologies of the Industrial Revolution embodied in machinery. This is a vision of the process of economic growth that is familiar to economic historians. The fit between their micro narratives and the macro patterns should lead them to place more confidence in their narratives of machinery investment and innovation. 
Summers and Jones stress that in the post-World War II period high machinery investment is strongly correlated with low relative prices of producer durables and rapid growth. If rapid growth causes increased machinery investment by increasing demand for machinery, it would raise the price of producer durables as well. The likelihood that the postWorld War II pattern reflects causation running from high machinery investment to rapid growth creates, if we are willing to write history backwards, a presumption that the same is true in the longer run as well.

\section{National Experiences}

The third piece of evidence comes from narrative histories of policy and growth in individual nations. Consider the case of Argentina. Argentinian long-run national income accounts are not sufficiently reliable for its inclusion in the database for the regressions. Neverthless, it is perhaps the most fascinating case study. Up to the late 1950's it was as rich as continental Europe, and had grown rapidly since large-scale settlement began in the mid-nineteenth century. In 1929 Argentina had been perhaps fifth in the world in automobiles per capita. In 1913 Buenos Aires had been in the top twenty among cities of the world in telephones per capita. Yet today Argentina is a third world country. Figure III plots the relative erosion of Argentine ouput per capita from levels comparable to Europe at the end of World War II.

Carlos Díaz Alejandro's Essays on the Economic History of the Argentine Republic provides a powerful-but controversial-analysis of Argentina's relative decline. The Depression had left Argentina justly 
suspicious of the free-trade order: its trading partners had shut it out of markets to preserve domestic employment. Political cleavages had sharpened as landowner and exporter elites showed eagerness to abandon democracy to stunt the welfare state. In this environment Juan Perón gained support for a program of national assertion and populist redistribution.

\section{Figure III: Post-World War II Argentine and European Real GDP per Capita Levels}

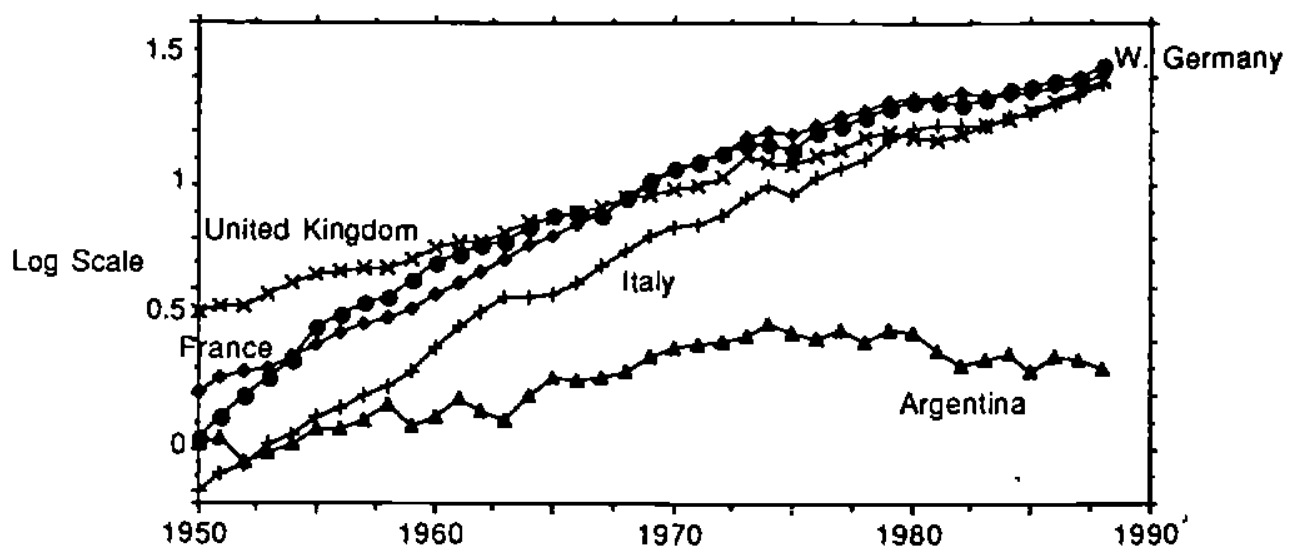

Source: Robert Summers and Alan Heston, "Penn World Table V."

Perón sought rapid economic growth and the redistribution of wealth to urban workers who had not received their fair share. His progran of stimulation, price controls, and wage raises produced almost half a decade of growth, but then exports fell as the disincentives implicit in his program made themselves felt. The resulting foreign exchange short- 
age gave Perón only unattractive options: devaluation and borrowing from abroad, thus betraying his nationalist commitments; internal austerity, causing unemployment and reversing his redistributions; or controls on imports to balance foreign payments by rationing iniported goods. Peron chose this third alternative, believing that growth, a continuation of redistribution, and a reduction in dependence on the world economy was good. First priority for foreign exchange went to raw materials to keep factories operating, second priority to consumption goods to keep workers' living standards high, and last priority to imports of capital goods for investment.

As a result, the early 1950's saw Argentina's relative prices of producer durables rise to more than twice world levels. Each percentage point of output saved and committed to the purchase of machinery produced less than one-half a percentage point's worth of real machinery investment. Even though the 1945-55 government boasted of industrialization, Díaz Alejandro found "[r]emarkably, the capital stock in electricity and communications increased by a larger percentage during the depression years 1929-39 than during 1945-55." Subsequent governments moderated but did not rollback Perónist policies. In spite of healthy savings, Argentinian rates of machinery investment have been low since World War II. And the economy has stagnated.

The case of post-World War II Argentina finds its opposite in postWorld War II West Germany. Post-World War II Argentina was thought to have a bright economic future. Post-World War II West Germany was seen as likely to require more than a generation to regain anything close 
to its previous relative economic position. Yet as figure III also shows, between 1950 and 1960 West German national product per capita gained 35 percent relative to France and 45 percent relative to Britain, leaving it in 1960 with productivity halfway between the two.

During this decade of the Wirtschaftswunder real returns on the German stock market averaged twenty-four percent per year. Such high rates of stock price growth indicate that Germany's growth leap of the 1950's was a surprise: had investors foreseen rapid economic growth, they would have bid stock prices up to higher levels in the early 1950's in anticipation. Belief in rapid growth of the magnitude seen in the Wirtschaftswunder was the exception, not the rule in post-World War II Germany. Thus it is not possible to claim that high machinery investment in Germany over 1950-65 was induced by a high demand for machinery by firms anticipating rapid economic growth, for by and large Germans did not anticipate the bright future that in fact lay ahead. If Germany's high machinery investment in the early post-World War II period is related to its growth miracle, it is as cause, not as consequence.

\section{Technology and Productivity}

The macro pattern sketched above is of a strong association between machinery investment and economic growth, an association that some evidence suggests reflects a strong causal chain running from high machinery investment to rapid growth. This macro pattern is consistent 
with a view of the micro structure of innovation that historians of tech nology have been drawing for generations. ${ }^{20}$ As Nathan Rosenberg puts it: “...inventions are relatively crude and inefficient [at first].... They are, of necessity, badly adapted to many of the[ir] ultimate uses... they offer only small advantages, or perhaps none at all." Rosenberg concludes that "the pace at which... improvements are made will be a major determinant of the rate of diffusion....improving a process contributes even more to technological progress than does its initial development."21

Consider three classic and exemplary studies. First, Fishlow's study of American railroad productivity found that over the forty years from 1870 to 1910 the lion's share of cost reduction was contributed by incremental changes in the design of freight cars and locomotives; one by one, these changes were small and barely noticed; but over forty years they added up to a doubling of the effective power of locomotives and to a tripling of the capacity of freight cars. 22 Second, a similar pattern holds in the past two decades in the computerized tomography industry: initial invention had relatively small benefits, but the subsequent explosion of innovation and adaptation changed a curiosity into a very valuable diagnostic device. The wave of small innovations-lhem-

\footnotetext{
20Nathan Rosenberg, "The Historiography of Technical Progress," in Inside the Black Bux (Cambridge: Cambridge University Press, 1982), excellently surveys work on the history of technology. Rosenberg's survey was written before Dayid Hounshell's excellent From the American System to Mass Production (Baitimore, MD: Johns Hopkins University Press. 1984). ${ }^{21}$ Rosenberg, Perspectives on Technology (Cambridge: Cambridge University Press, 1976). 22 Albert Fishlow, "Productivity and Technological Change in the Railroad Sector," in D. Brady. ed., Output, Employment, and Productivity in the United States After 1800 (New York: NBER, 1966).
} 
selves separate from although unthinkable without the initial invention-contributed the lion's share of the value of the innovation. ${ }^{23}$ Third, recall Hunter's famous study of the development of the steamboat; both the engine and the principles of ship design were borrowings from Britain, yet the developed American steamboat had a different kind of engine, a different strength of frame, a different shape of hull, a different form of superstructure-no feature of the original British design was kept without major modification. 24

Case studies cannot prove a general pattern. Nevertheless, it is worth noting that historians who have examined the process of technological development have for the most part stressed the process of feedback and incremental improvements in operation and design. A similar stress on incremental improvements can be found in studies of teclnology adaptation by countries not at the forefront of invention and innovation. How are such incremental improvements made? Clearly they can only be made by those who are already very familiar with the technology and its uses. Without workers and managers with hands-on experience the process of technology transfer and technological adaptation becomes impossibly difficult. Feedback from users and small adaptations of machines and organizations lies at the heart of the stories of productivity growth narrated by technological historians. Such a pattern strongly

\footnotetext{
${ }^{23}$ See Manuel Trajtenberg, Economic Analysis of Product Innovation (Cambridge, MA: Harvard University Press, 1990). Similar pattems can be found even in teclnnologies that appear at first glance stable.

${ }^{24}$ Louis Hunter, Steamboats on the Western Rivers (Cambridge, MA: Harvard University Press, 1949).
} 
suggests that rapid productivity growth requires intimate experience with-and abundant accumulation of-the machinery in which the technologies that need to be adapted are embodied.

Thus the macro association of machinery investment and growth and the micro studies in the history of technology may be pieces of the same puzzle. On the macro side, rapid machinery accumulation is associated with rapid productivity growth, and appears to yield social benefits to the economy in terms of higher productivity that dwarf the profits that the owners of the capital goods installed are able to privately appropriate. On the micro side, active experience with technologies is a necessary prerequisite to developing them further or to using them productively.

The association between machinery investment and growth in this sample is very strong. The estimated coefficients suggest that each additional percentage point of total output devoted to investment in machinery raises output per worker growth by more than half a percentage point per year. This might be taken to imply a gross social rate of return on equipment investment of more than fifty percent per year-or a net social payback period of three years or less even allowing for very rapid depreciation of machinery.

This high estimate may be too high. The nations in the sample are, today, wealthy and successfully industrialized economies. Circunstances have broken in their favor over the past century. The high coefficient may to some degree be capturing the good luck that the countries in the sample have had. A different sample night well have led to 
different conclusions.

One obvious addition to the sample that would have led to different conclusions is the Soviet Union: since Stalin took absolute power at the end of the 1920's, the Soviet Union has invested extraordinarily heavily in machinery, and yet achieved productivity growth rates very poor by the standards of the industrial West. The inefficiency of the Soviet economy at translating inputs into outputs is one of the most fascinating and heartbreaking stories of the economic history of the twentieth century. Yet its experience serves as a warning to governments seeking to industrialize and accelerate growth: the type of machinery investment that leads to rapid growth appears to be the type generated by private firms and market allocation processes, not by central planners.

Nevertheless, the experience of the past century is that those countries that have grown most rapidly have been those that have invested very heavily in machinery. There is a strong case that their rapid growth is in large part due to this investment: it enabled their workers and firms to gain experience at using and thus master the technologies of the Industrial Revolution embodied in machinery. This is a vision of the process of economic growth that is familiar to economic historians. The fit between their micro narratives and the macro patterns should lead them to place more confidence in their narratives of machinery investment and innovation. 